Gut, 1981, 22, 19-24

\title{
Description and basic cell kinetics of the murine pericryptal fibroblast sheath
}

\author{
J V NEAL AND C S POTTEN \\ From the Paterson Laboratories, Christie Hospital, and Holt Radium Institute, Manchester
}

SUMmARY The size of the pericryptal fibroblast sheath (PCFS) population was determined by scoring serial sections. There are 38 and 124 PCFS cells per murine small intestinal and colonic crypt, respectively. The cells of the PCFS are slightly weighted towards the lower two-thirds of the crypt in their distribution. The ratio of epithelial cells to PCFS cells is approximately $6 \cdot 5: 1$. The in vivo cell kinetics were analysed under control and stressed (fasted-refed) conditions. The control labelling index increases from $8.9 \%$ in the small intestine and $7.0 \%$ in the colon to peaks $49 \%$ and $113 \%$ respectively above these values 24 hours after ${ }^{3} \mathrm{HTdR}$ administration. Labelling is observed at all crypt levels equally, and no evidence of vertical migration of labelled PCFS cells was found. Colonic epithelial and PCFS cells show a similar pattern of response to feeding after a fast of 72 hours with respect to time, but a different distribution of response in terms of crypt position.

The kinetics of the epithelial cells of the gastrointestinal tract have been the subject of exhaustive study for over 30 years. ${ }^{1-8}$ The underlying connective tissue has received comparatively little attention. The lamina propria contains a mixture of mesenchymal (large haematopoietic-derived) cell types. ${ }^{9}$ Fibroblasts have been noted to be common in the zone immediately subjacent to the epithelium. ${ }^{910}$ Pascal and his colleagues ${ }^{11}$ named '... this distinct and highly organised system of fibroblasts, collagen and mucopolysaccharide ground substance ... the "pericryptal fibroblast sheath" (PCFS)'.

Although the ultrastructural features of the PCFS have been described in several tissues and species ${ }^{12-14}$, no estimate of the size of the PCFS population has been made. Only scanty information exists on the distribution of PCFS cells around the crypt. ${ }^{1516}$

Uptake of tritiated thymidine $\left({ }^{3} \mathrm{HTdR}\right)$ by the cells of the PCFS has been demonstrated. ${ }^{11}{ }^{13-18}$ These reports all suggested proliferative activity in the PCFS as illustrated by increases in labelling index (LI) and grain dilution with time. This was despite the consistent failure to detect compatible levels of mitotic activity, ${ }^{11}{ }^{15}$ (Marsh, personal communication). Furthermore, it was stated that labelled PCFS cells migrated in approximate synchrony with the adjacent labelled epithelial cells, ${ }^{11} 1318$ although this could not be demonstrated in the rat colon. ${ }^{16}$

Received for publication 12 September 1980
In this report the size and distribution per crypt of the PCFS population in the mouse was determined. The level and distribution of ${ }^{3} \mathrm{HTdR}$ uptake under normal as well as stressed (fasted-refed) conditions was studied, with special emphasis being placed on the detailed comparison of the behaviour of the PCFS and the epithelium.

\section{Methods}

Eleven 12 week old male DBA $/ 2 \mathrm{~J}$ mice were used in these experiments. They were fed standard diet (PMD) (Oakes of Congleton, Cheshire); given tap water; and housed, treated, and killed in groups of four. During starvation wood shavings were replaced with Sorbitex-375 (Savilles Hydrological Corpn. London), an inedible absorbent bedding, and tap water continued to be supplied ad libitum. Twenty-five $\mu \mathrm{Ci}$ doses of ${ }^{3} \mathrm{HTdR}$ (Amersham), (specific activity $5 \mathrm{Ci} / \mathrm{mM}$ ), were administered intraperitoneally. Vincristine sulphate $(1 \mathrm{mg} / \mathrm{kg})($ Oncovin, Lilly, Basingstoke) was administered in the same way. Paraffin-embedded samples of small intestine and distal colon were sectioned at $5 \mu \mathrm{m}$ for routine autoradiography. Ilford K5 emulsion, two week exposure, and trichrome haematoxylinphloxin-saffron (HPS) stain $^{19}$ were used. Fifty crypt sides per tissue per mouse were scored; small intestinal crypts were selected having a minimum of 17 cells per side and colonic crypts having a minimum of 35 . These limits were selected arbitrarily 
from initial observations on longitudinal crypt sections where the entire crypt was believed to be represented. The actual number of epithelial cells along each crypt side was then subdivided into three regions-bottom, middle, and upper thirds. These thirds marked the boundaries for all parameters scored. PCFS cells were recognised by nuclear morphology, proximity to the subepithelial surface, and staining characteristics. The labelling index (LI) values reported here present single values taken at $\mathbf{0 9} .00$ hours. There is, in fact, a circadian fluctuation in PCFS LI which has its peak at about 03.00 and 09.00 hours for small intestine and colon respectively. ${ }^{20}{ }^{21}$ PCFS population size determinations were made by two methods using serial sections either through crypts cut longitudinally at $2 \mu \mathrm{m}$ (eponAraldite-embedded, Basic Fuchsin and Toluidine Blue $\mathrm{O}$ stained), or through crypts cut transversely at $7 \mu \mathrm{m}$ (paraffin-embedded, HPS stained). Photographs of the sections were used to build up threedimensional reconstructions of small intestinal and colonic crypts.
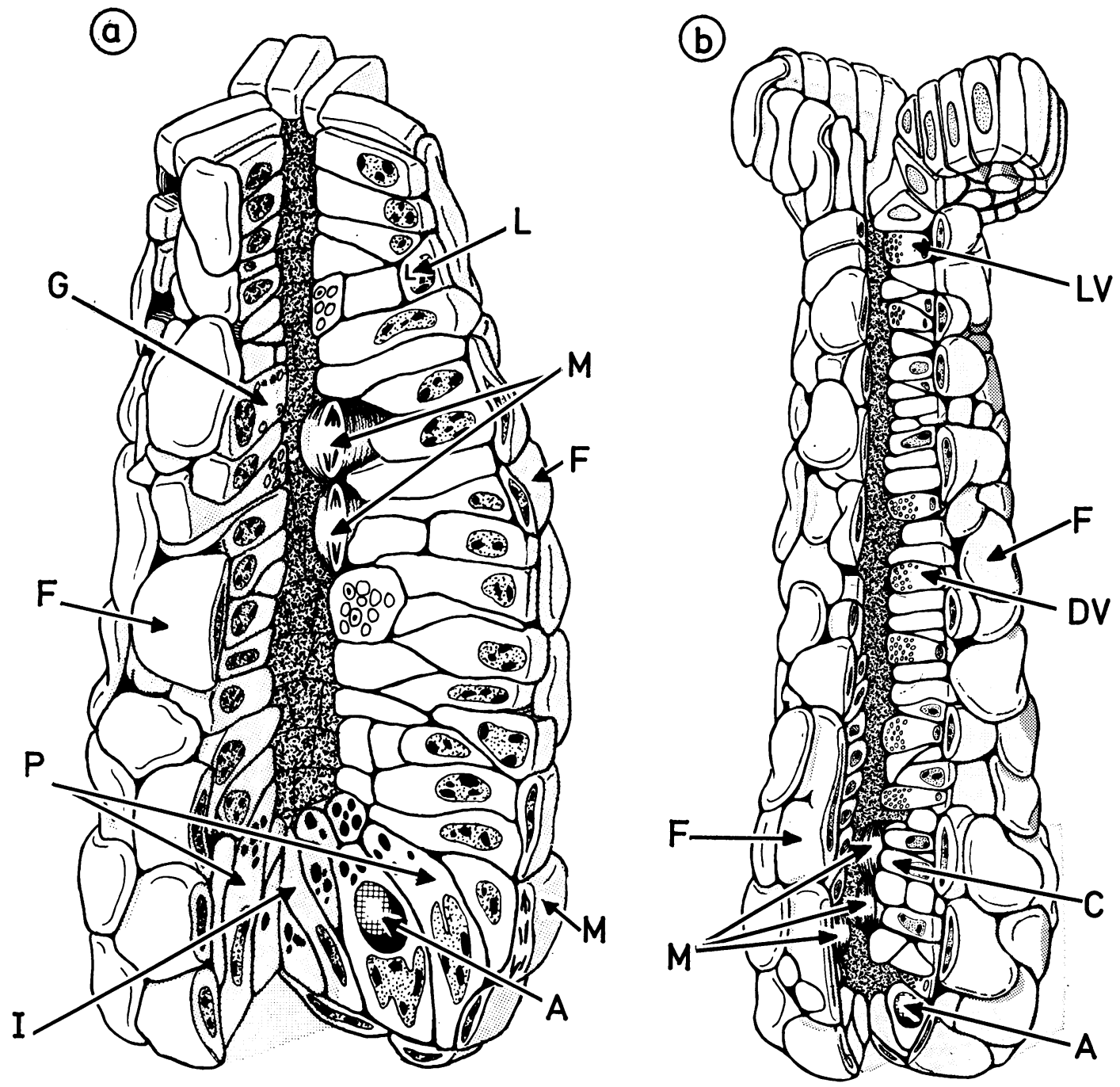

Fig. 1 (a) Three-dimensional reconstruction of a small intestinal crypt based on an identification, classification and positioning of each cell in the crypt. F: PCFS cell, M: mitosis, G: goblet cell, $L:$ lymphocyte, $P:$ Paneth cell, $A$ : apoptosis, I: indeterminate cell, Unlabelled: columnar cell. (b) Three-dimensional reconstruction of a colonic crypt. F: PCFS cell, LV: light vacuolated cell, DV: dark vacuolated cell, C: columnar cell, M: mitosis, A: apoptosis. 


\section{Results}

The PCFS forms a virtually complete layer around the small intestinal and colonic crypt (Fig. 1). The total size of the PCFS population was determined in both the small intestine and colon by identifying fibroblast sheath cells by their nucleus in one section, and following each nucleus in consecutive sections until it disappeared. In this way the PCFS was counted in serial sections cut through the crypt longitudinally at $2 \mu \mathrm{m}$, or transversely, at $7 \mu \mathrm{m}$ (Table 1). Although relatively small numbers of crypts were analysed by these techniques the distribution of cells around the crypt was found to be similar in both tissues (Table 2), there being a slight preponderance of PCFS cells around the lower two-thirds of the crypt. The number of epithelial

Table 1 Size of PCFS population per crypt as determined by two methods

\begin{tabular}{lll}
\hline Serial sections & \multicolumn{2}{l}{ Population size estimates } \\
\cline { 2 - 3 } & Small intestine & Colon \\
\hline $2 \mu \mathrm{m}$ longitudinal & $41(4)$ & $125(1)$ \\
$7 \mu \mathrm{m}$ transverse & $35(7)$ & $123(6)$ \\
\hline
\end{tabular}

The numbers in parentheses indicate the number of crypts (all taken from one mouse) scored using each method.

Table 2 Percentage distribution of PCFS cells around serially sectioned crypts

\begin{tabular}{lll}
\hline & \multicolumn{2}{l}{ Distribution ofPCFS cells (\%) } \\
\cline { 2 - 3 } & Small intestine & Colon \\
\hline Bottom third & $38 \cdot 1$ & $39 \cdot 3$ \\
Middle third & 36.9 & $31 \cdot 6$ \\
Upper third & $25 \cdot 4$ & 28.7 \\
\hline
\end{tabular}

cells per crypt was found to be 270 in the small intestine and 745 in the colon, using the $2 \mu \mathrm{m}$ serial sections. The ratio of epithelial cells to PCFS cells was therefore $7 \cdot 3: 1$ and $6: 1$ in the small intestine and colon respectively. Because only a few crypts were analysed by the serial reconstruction technique, indirect techniques (based on counts of PCFS cells obtained from many single paraffin sections and measurements of crypt and cell nuclear size) were also used. These provided similar values for population size. ${ }^{20}$

The change in labelling index with time after a single injection of ${ }^{3} \mathrm{HTdR}$ is presented in Table 3. The PCFS LI rose from an initial level of $8.9 \%$ to a peak of $13.3 \%$ at 24 hours in the small intestine; an increase of $49 \%$. In the colon the initial LI of $7.0 \%$ rose to a peak of $14.9 \%$ at 24 hours, an increase of $113 \%$. The LI at all three crypt levels was similar and no suggestion of vertical migration of labelled PCFS cells could be found. Very few mitoses in the PCFS were seen. In a separate experiment only 10 PCFS mitoses were found along 6400 crypt sidesthat is, about 19000 PCFS cells (the tissues studied were small intestine, caecum, and colon).

Seventy-two hours' starvation produced a marked decline in LI in both the PCFS and epithelial cells of the colon (Fig. 2a). The LI of both cell populations responded rapidly to refeeding, reaching peaks at around 16 hours after refeeding. Vincristine sulphate was used in a separate experiment to accumulate mitoses during the period after refeeding. A surge in mitotic activity was noted in the epithelium and in the lamina propria, but not in the PCFS, 13.5 to 15.5 hours after refeeding. This coincided with an increase in the number of epithelial cells per crypt side (Fig. 2b). The response in LI after refeeding was confined to the epithelial cells in the bottom third of the crypt, and to the PCFS around the lower two-thirds.

Table]3 Change in PCFS labelling index (LI) with time after single intraperitoneal injection of ${ }^{3} H T d R$

\begin{tabular}{|c|c|c|c|c|c|c|c|c|}
\hline & \multicolumn{8}{|c|}{ PCFS labelling index (\%) } \\
\hline & \multicolumn{4}{|c|}{ Small intestine } & \multicolumn{4}{|l|}{ Colon } \\
\hline & Total & Bottom & Middle & Upper & Total & Bottom & Middle & Upper \\
\hline Hours & & & & & & & & \\
\hline $\begin{array}{r}0.5 \\
6.0 \\
12.0\end{array}$ & $\begin{array}{r}8.9 \pm 0.9 \\
9.7 \pm 1.0 \\
12.5 \pm 1.5\end{array}$ & $\begin{array}{l}6 \cdot 5+3 \cdot 4 \\
4 \cdot 2 \pm 1 \cdot 1 \\
5 \cdot 4 \pm 3 \cdot 4\end{array}$ & $\begin{aligned} 14 \cdot 0 & \pm 2 \cdot 8 \\
9 \cdot 2 & \pm 1 \cdot 1 \\
13.0 & \pm 1 \cdot 6\end{aligned}$ & $\begin{array}{r}5 \cdot 5 \pm 2 \cdot 2 \\
18 \cdot 3 \pm 5 \cdot 7 \\
21 \cdot 5 \pm 3 \cdot 9\end{array}$ & $\begin{array}{l}7 \cdot 0 \pm 0.9 \\
7 \cdot 9 \pm 0.9 \\
9 \cdot 6 \pm 1 \cdot 3\end{array}$ & $\begin{aligned} 4 \cdot 7 & \pm 1 \cdot 4 \\
10 \cdot 1 & \pm 1 \cdot 1 \\
9 \cdot 0 & \pm 2 \cdot 3\end{aligned}$ & $\begin{array}{l}8 \cdot 1 \pm 1 \cdot 8 \\
5 \cdot 8 \pm 2 \cdot 0 \\
9 \cdot 5 \pm 2 \cdot 8\end{array}$ & $\begin{array}{r}8 \cdot 8 \pm 3 \cdot 4 \\
7 \cdot 4 \pm 3 \cdot 1 \\
10 \cdot 4 \pm 2 \cdot 8\end{array}$ \\
\hline $\begin{array}{l}\text { Days } \\
1.0 \\
2.0 \\
3.0 \\
7.0\end{array}$ & $\begin{array}{r}13 \cdot 3 \pm 2 \cdot 5 \\
9 \cdot 9 \pm 1 \cdot 1 \\
2 \cdot 5 \pm 1 \cdot 5 \\
1 \cdot 7+1 \cdot 0\end{array}$ & $\begin{array}{r}10 \cdot 3 \pm 3 \cdot 2 \\
7 \cdot 3 \pm 1 \cdot 4 \\
1 \cdot 5 \pm 0.8 \\
2 \cdot 4 \pm 1 \cdot 5\end{array}$ & $\begin{array}{l}8 \cdot 9 \pm 5 \cdot 3 \\
9 \cdot 2 \pm 1 \cdot 3 \\
3 \cdot 0 \pm 3 \cdot 0 \\
1 \cdot 2 \pm 1 \cdot 2\end{array}$ & $\begin{array}{r}21 \cdot 5 \pm 3 \cdot 9 \\
16 \cdot 5 \pm 5 \cdot 0 \\
5 \cdot 1 \pm 3 \cdot 2 \\
1 \cdot 1 \pm 1 \cdot 1\end{array}$ & $\begin{array}{r}14.9 \pm 2.6 \\
10.7 \pm 0.9 \\
14.0 \pm 1.9 \\
5.2 \pm 0.8\end{array}$ & $\begin{array}{r}13 \cdot 8 \pm 3 \cdot 2 \\
5 \cdot 4 \pm 1 \cdot 1 \\
11 \cdot 3 \pm 0 \cdot 1 \\
3 \cdot 0 \pm 1 \cdot 1\end{array}$ & $\begin{array}{r}14 \cdot 2 \pm 2 \cdot 9 \\
10 \cdot 7 \pm 2 \cdot 0 \\
13 \cdot 6 \pm 2 \cdot 4 \\
5 \cdot 3 \pm 1 \cdot 1\end{array}$ & $\begin{array}{r}18 \cdot 2 \pm 2 \cdot 9 \\
18 \cdot 4 \pm 4 \cdot 9 \\
17 \cdot 7 \pm 1 \cdot 1 \\
7 \cdot 9 \pm 2 \cdot 7\end{array}$ \\
\hline
\end{tabular}

Data are presented for the crypt as a whole, and also for each of the three crypt levels separately; and are expressed in terms of a mean \pm SE of data from four animals. The labelling indices for each crypt third and for the PCFS as a whole were computed separately and because of the uneven distribution in PCFS cells, the total LI will only approximately equal the average of the three crypt regions. 


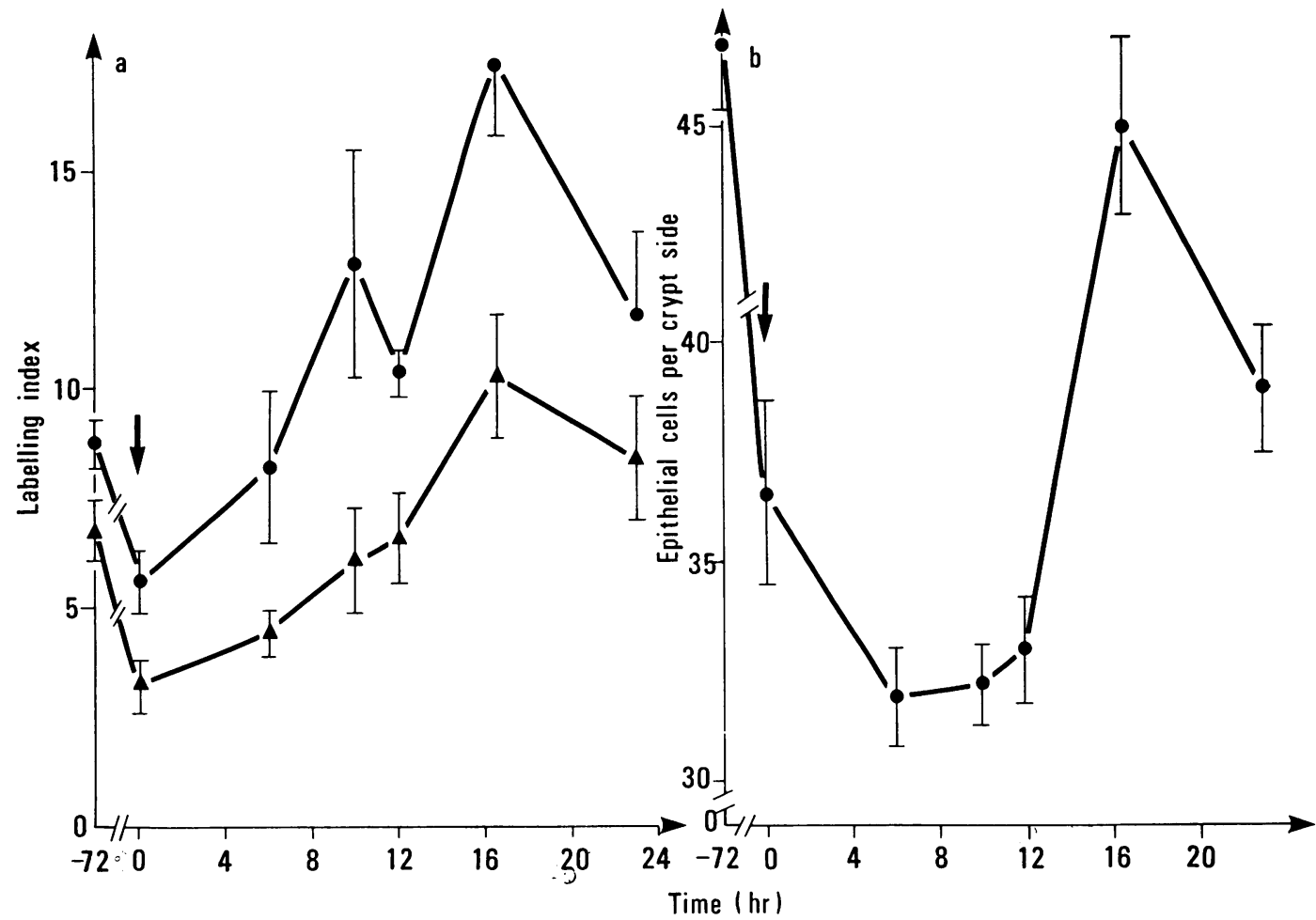

Fig. 2 (a) The change in colonic PCFS ( $\mathbf{)}$ ) and epithelial (0) Labelling Index after 72 hours' starvation and refeeding (arrow). (b) Change in the number of epithelial cells per colonic crypt side during 72 hours' starvation and after refeeding (arrow). For the scoring of this parameter only the 35-cell-per-crypt minimum was suspended, and any crypt with a good longitudinal profile was accepted.

\section{Discussion}

The population size data presented here are the first such estimates to be produced for the PCFS. The distribution of PCFS cells around the murine small intestinal and colonic crypt is similar to that reported for the human rectal ${ }^{15}$ and the rat colonic ${ }^{16}$ PCFS. The ratio of epithelial cells to fibroblasts was reported to increase with position up the rabbit colonic crypt ${ }^{11}$ indicating fewer PCFS cells around the upper crypt third. The ratios reported (of 54:1 and 70:1 for the lower and upper third of the crypt respectively) were 10 times higher than those reported here for the murine PCFS.

Labelling of cells in the lamina propria by ${ }^{3} \mathrm{HTdR}$ has been noted previously. ${ }^{22-27}$ Subepithelial fibroblasts in the rabbit gall bladder were noted to label with ${ }^{3} \mathrm{HTdR} .^{25}$ Studies concerning the uptake of ${ }^{3}$ HTdR by cells of the PCFS have been conducted in several tissues in different species. Early reports suggested that labelling was initially confined to the lower levels of the PCFS ${ }^{11} 1317$ but this was found not to be the case in the human rectal ${ }^{15}$ and rat colonic ${ }^{16}$ PCFS, nor could an uneven distribution of PCFS labelling be confirmed in this study in either the small intestine or colon.

The labelling index found in these experiments (of about $7 \%$ ) was higher than those reported in the murine jejunal subepithelial fibroblast sheath (where the subepithelial fibroblast layer in the villus has been included) ${ }^{18}$ and in the rat colonic PCFS ${ }^{16}$, but comparable with that of the human rectal PCFS. ${ }^{15}$ The time of peak labelling ( 24 hours) was the same as that found in the rabbit jejunal ${ }^{13}$ and rat colonic ${ }^{16}$ PCFS, but earlier than that previously reported in the mouse jejunum. ${ }^{18}$

The increase in LI between the initial level and peak level agrees with observations in the rat colon ${ }^{16}$ and is in contrast with previous data in the mouse jejunum. ${ }^{18}$ This increase, which is subject to large errors, suggests only a low level of proliferative activity. This moderate increase in LI over the first 24 hours after ${ }^{3} \mathrm{HTdR}$ uptake can be attributed to several possible causes: (1) partially to the low level 
of mitotic activity, (2) any delayed uptake of ${ }^{3} \mathrm{HTdR},{ }^{26}$ (3) an inflow of labelled cells from the lamina propria, (4) an outflow of mature cells which might be more likely to be unlabelled. The extremely low level of mitotic activity alone is unlikely to account for the increase in labelling. There is an apparent conflict between the initial labelling levels and the very low mitotic activity, unless we assume that the ratio of $\mathbf{S}$ to $\mathbf{M}$ phase lengths is remarkably high. However, data presented elsewhere suggest that most of the labelling with ${ }^{3} \mathrm{HTdR}$ in the PCFS leads to endoduplication resulting in several ploidy classes in the PCFS. ${ }^{20}{ }^{27}$

In accordance with observations in the rat colon ${ }^{16}$ and in contrast with all other previous results ${ }^{11} 1317$ migration of labelled PCFS cells with the labelled epithelial cells towards the gut lumen could not be demonstrated.

The timing of the response of colonic epithelial cells to refeeding after 72 hours' starvation is in agreement with previous reports..$^{28-33}$ The pattern of change in PCFS LI with time precisely mimics that of the epithelial LI, indicating that the mechanism which promotes this burst in DNA-synthetic activity must influence both cell populations. Tissue distension by food bulk, permitting increased vascular flow, ${ }^{32}$ could serve this purpose. The refeeding response was confined to the epithelial cells of the bottom third of the crypt and to the PCFS around the lower two-thirds.

There was no surge in mitotic activity in the PCFS even after the burst in DNA-synthetic activity after refeeding. Increased mitotic activity did occur in the lamina propria and epithelium, and this coincided with an increase in crypt size. Crypt size has previously been reported both to decline during starvation $^{29}$ and not to decline. ${ }^{30}$

In summary, the PCFS shows significant levels of ${ }^{3} \mathrm{HTdR}$ incorporation, which is evenly distributed along the crypt. Mitotic activity compatible with such ${ }^{3} \mathrm{HTdR}$ incorporation was not observed. No vertical migration of labelled PCFS cells could be found and the distribution along the crypt of response labelling of the PCFS to refeeding differed from that of the adjacent epithelial cells, although the timing of response was similar. These results indicate that the proposed translocation of epithelialmesenchymal units ${ }^{11} 131734$ does not occur, despite the harmony of epithelial cells and PCFS response on a whole-crypt basis.

This work was conducted at the Paterson Laboratories and supported by grants from the Cancer Research Campaign and the Medical Research Council. Our thanks go to the Pathology Department for the processing of histological material and
Hilary Goodwin for typing this report. We are also grateful to Don Major for some helpful discussions.

\section{References}

${ }^{1}$ Leblond CP, Stevens CE. The constant renewal of the intestinal epithelium in the albino rat. Anat Rec, 1948; 100: 357-77.

${ }^{2}$ Quastler H, Sherman FG. Cell population kinetics in the intestinal epithelium of the mouse. Exp Cell Res $1959 ; 17: 420-38$.

${ }^{3}$ Fry RJM, Lesher S, Kisiekski WF, Sacher G. Cell proliferation in the small intestine. In: Lamerton FL, Fry RJM, eds, Cell proliferation Oxford: Blackwell, 1963:213-35.

${ }^{4}$ Cairnie AB, Lamberton FI, Steel GG. Cell proliferation studies in the intestinal epithelium of the rat. I. Determination of the kinetic parameters. Exp Cell Res 1965; 39: 528-38.

${ }^{5}$ Cheng H, Leblond CP. Origin, differentiation and renewal of the four main epithelial cell types. Am J Anat 1974; 141 : 503-20.

${ }^{6}$ Wright NA, Al-Dewachi HS, Appleton DR, Watson AJ. Cell population kinetics in the rat jejunal crypt. Cell Tissue Kinet 1975; 8: 361-8.

${ }^{7}$ Rijke RPC, Plaisier HM, Langendoen NJ. Epithelial cell kinetics in the descending colon of the rat. Virchow Archiv. B. Cell Pathol. 1979; 30: 85-94.

${ }^{8}$ Potten CS. Stem cells in small-intestinal crypts. In: Appleton DR, Sunter JP, Watson AJ, eds. Cell proliferation in the gastrointestinal tract. Pitman Medical Press. 1980: 141-54.

${ }^{9}$ Deane HW. Some electron microscope observations of the lamina propria of the gut with some comments on the close association of macrophages, plasma cells and eosinophils. Anat Rec 1964; 149: 453-74.

${ }^{10}$ Donnellan WL. The structure of the colonic mucosa. Gastroenterology 1965; 49: 496-314.

"Pascal RR, Kaye GI, Lane N. Colonic pericryptal fibroblast sheath: replication, migration and cytodifferentiation of a mesenchymal cell system in adult tissue. I. Autoradiographic studies of normal rabbit colon. Gastroenterology 1968; 54: 835-51.

${ }^{12}$ Kaye GI, Lane N, Pascal RR. Colonic pericryptal fibroblast sheath: replication, migration and cytodifferentiation of a mesenchymal cell system in adult tissue. II. Fine structural aspects of normal rabbit and human colon. Gastroenterology 1968; 54: 852-65.

${ }^{13}$ Parker FG, Barnes EN, Kaye GI. The pericryptal fibroblast sheath. IV. Replication, migration and differentiation of the subepithelial fibroblasts of the crypt and villus of the rabbit jejunum. Gastroenterology 1974; 67: 607-21.

${ }^{14}$ Marsh MN, Trier JS. Morphology and cell proliferation of the sub-epithelial fibroblasts in adult mouse jejunum. I. Structural features. Gastroenterology 1974; 67: 622-35.

${ }^{15}$ Wiernik G, Perrins D. The radiosensitivity of a mesenchymal tissue. The pericryptal fibroblast sheath in the human rectal mucosa. Br J Radiol 1975; 48: 382-9. 
${ }^{16}$ Maskens AP, Rahier JR, Meersseman FP, DujardinLoits R-M, Haot JG. Cell proliferation of pericryptal fibroblasts in the rat colon mucosa. Gut 1979; 20: 775-9.

${ }^{17}$ Kaye GI, Pascal RR, Lane N. The pericryptal fibroblast sheath: replication migration and cytodifferentiation of a mesenchymal cell system in adult tissue. III. Replication and differentiation in human hyperplastic and adenomatous polyps. Gastroenterology 1971; 60: 51536.

${ }^{18}$ Marsh MN, Trier JS. Morphology and cell proliferation of sub-epithelial fibroblasts in adult mouse jejunum. II. Radioautographic studies. Gastroenterology 1974; 67: 636-45.

${ }^{19}$ Bencosmé SA. A trichrome staining method for routine use. Am J Clin Pathol, 1954; 24: 1324-8.

${ }^{20}$ Neal JV. Ph.D. Thesis, University of Manchester (1980).

${ }^{21}$ Neal JV, Potten CS. Circadian rhythms in the epithelial cells and the pericryptal fibroblast sheath in three different sites in the marine intestinal tract. Cell Tiss Kinet 1981. (In press).

${ }^{22}$ Pelc SR. Labelling of DNA and cell division in so-called non-dividing tissues. J Cell Biol 1964; 22: 21-8.

${ }^{23}$ Troughton WD, Trier JS. Paneth and goblet cell renewal in mouse duodenal crypts. J Cell Biol 1969; 41 : 251-67.

${ }^{24}$ Cairnie AB. Renewal of goblet and Paneth cells in the small intestine. Cell Tissue Res 1970; 3: 35-45.
${ }^{25}$ Kaye GI, Maenza RM, Lane N. Cell replication in rabbit gall bladder. Gastroenterology 1966; 51 : 670-80.

${ }^{26}$ Potten CS. Further observations in the late labelling associated with stimulus-responsive cells in skin. Cell Tissue Kinet 1973; 6: 553-66.

${ }^{27}$ Neal JV, Potten CS. Polyploidy in the marine colonic pericryptal fibroblast sheath. Cell Tiss Kinet 1981. (In press.)

${ }^{28}$ Clarke RM. The time-course of changes in mucosal architecture and epithelial cell production and shedding in the small intestine of the rat fed after fasting. $J$ Anat 1975; 120: 321-7.

${ }^{29}$ Al-Dewachi HS, Wright NA, Appleton DR, Watson AJ. The effect of starvation and refeeding on cell population kinetics in the rat small bowel mucosa. $J$ Anat 1975; 119: 105-21.

${ }^{30}$ Hagemann RF, Stragand JJ. Fasting and refeeding: Cell kinetic response of jejunum, ileum and colon. Cell Tissue Kinet 1977; 10: 3-14.

${ }^{31}$ Stragand JJ, Hagemann RF. Dietary influence on colonic cell renewal. Am J Clin Nutr 1977; 3: 918-23.

${ }^{32}$ Stragand JJ, Hagemann RF. Effect of lumenal contents on colonic cell replacement. Am J Physiol 1977; 233: 208-11.

${ }^{33}$ Stragand JJ, Hagemann RF. An iron requirement for the synchronous progression of colonic cells following fasting and refeeding. Cell Tissue Kinet 1978; 11: 513-8.

${ }^{34}$ Zajicek G. The intestinal proliferation. $J$ Theoret Biol 1977; 67: 515-23. 